DOI:10.2478/rrlm-2019-0009

\title{
To translate or not to translate medical texts? This is the dilemma!
}

\author{
Adrian Naznean* \\ The University of Medicine, Pharmacy, Science, and Technology of Târgu Mureș, Romania
}

Received: $26^{\text {th }}$ November 2018; Accepted: 29 ${ }^{\text {th }}$ December 2018; Published: $6^{\text {th }}$ January 2019

\section{Introduction}

Undoubtedly, with English as the lingua franca of science due to the "dominant role of the U.S. in computer science and technology" (1), and, moreover, that of health and medical sciences, an enormous amount of articles is published on a daily basis. Scientists worldwide strive to have their work published in highly ranked journals. Consequently, in order to disseminate knowledge, "scientific texts are now increasingly written with international consumption in mind" (2). However, not all scientists are proficient speakers of English, and, as such, many linguistic inconsistencies make their way into printed versions. On the other hand, as far as the corpus of this study is concerned, it is unknown to what extent published articles are translations from the authors' source language or whether they have been produced in English by the authors themselves. As far as translations are concerned, the profession of medical translator is rather sparse and freelance translators are reluctant to accept such commissions due to the fact that a medical translator is expected to possess some medical knowledge apart from linguistic skills in both the source and target languages.

Whether we assume that many articles are translations made by translators or may have been written in English by the authors themselves, in which case we deal with self-translations, translation problems do occur, which, in the view of Montalt \& González Davies (3), are verbal or non-verbal segments that can be present either in a text segment, that is, on a micro level, or in the text as a whole, namely, on the macro level. As a language editor of a medical journal, I have reviewed dozens of medical articles, few of which can be said to have been truly well-written from the point of view of English language. As such, I would like to highlight some types of recurring errors that writers (i.e. authors and/ or translators) frequently make. However, a distinction between language and terminological errors should be made. As a result, while a scientist is more likely to make language (i.e. grammar, vocabulary, etc.) errors, a translator may be prone to making terminological ones (wrong choice of terms, for instance). In an ideal situation, the best

\footnotetext{
*Corresponding author: Adrian Naznean, The University of Medicine, Pharmacy, Science, and Technology of Târgu Mureș, Romania. E-mail: adrian.naznean@umftgm.ro
} 
solution is that translators work together with the author(s) of the source text.

\section{Study design}

While there are many types of medical texts, such as biomedical articles, case reports, package inserts, textbooks, manuals for medical equipment, official regulations (4), the most important is the biomedical article as it is the means by which researchers make their work known to other scientists in the field. This study is based on a corpus of 20 articles randomly selected from different issues of two journals published in Romania, both journals are ISI indexed in the Core Collection of Clarivate Analytics (Web of Knowledge), and both are published in English. Topics covered by the articles range from heart diseases to pharmaceutical ones, and all of the articles are authored by Romanian scientists. The articles included in the corpus are of two types: original research and case studies. As an experienced medical translator and reviewer of biomedical research articles, I assume that most of the articles in the corpus have been produced in English by the authors themselves, with very little or no involvement of an English language professional.

The findings of this study and correction suggestions are to be regarded as practical advice on the dos and don'ts of medical translation, aimed at both authors and translators working with biomedical texts.

\section{Findings}

The entire corpus of texts that is at the basis of this study was processed manually. Starting from the assumption that the articles included in the corpus were written in English by the researchers themselves or are self-translations of the Romanian source texts, that is written in Romanian by the authors and translated by themselves, I divided the different types of linguistic inconsis- tencies, as I prefer to call them rather than mistakes, under the following 11 headings:

- plural nouns used as adjectives

- the use of that

- plural nouns with singular verbs

- the case of et al.

- problems related to the use of prepositions

- empty subjects

- extra words

- wrong choice of words

- wrong choice of tense

- wrong word order

- incomplete sentences and missing words.

\section{Plural nouns used as adjectives}

From a quantitative point of view, one of the most commonly occurring problems is the use of a plural noun as an adjective, whereas a singular noun should be used. This may be rooted in the fact that authors are unaware of the fact that the English adjective does not have plural forms unlike other languages (i.e. Romanian). Thus, "lesions assessment" is the wrong for lesion assessment. For another example: "effects computation and plotting was carried out with the "effects" $\mathrm{R}$ package". The list may continue with: "hydro-alcoholic extracts obtained from waste materials resulted in the essential oils extraction process during thyme and oregano distillation"; "after volatile oils removal, wasted plant materials are still abundant in phenolic compounds"; "on the other hand, chronic hyperglycaemia will cause changes in the structure and functions of erythrocytes membrane by increasing their aggregation ability and reducing the deforming capacity". Since the mother tongue of all the authors of these articles is Romanian, we assume that what they were thinking about when producing the target text was: ... în procesul extracţiei uleiurilor esenţiale; după înlăturarea uleiurilor volatile; hiperglicemia cronică va cauza modificări în structura şi funcţiile membranei eritrocitelor, 
all of which are used as nouns in Romanian and thus have plural forms.

Similarly, a common error based on the same crosslinguistic pollution is the case of ages accompanied by numbers as in the following examples: "this 32 years old patient, with 16 induced abortions in the physiological history, presented one year ago"; and a part of the title of one of the articles: "A 4 years study in diabetic chronic kidney disease patients on ketoaminoacids treatment". All these three nouns would be plural in Romanian, namely pacientă în vârstă de 32 de ani, studiu de 4 ani, and tratament cu cetoaminoacizi.

Advice: use singular nouns when they are adjectives (i.e. 32-year-old patient, essential oil extraction, etc.).

\section{The use of that}

Another common problem is the use of that in relative clauses when referring to human subjects, as well as its use in non-defining relative clauses. This is obviously frequently encountered because a plethora of biomedical articles is about research on human beings or case reports. While using that when referring to human beings is acceptable in speech, it should be avoided in the production of written texts. On the other hand, the use of that is strictly restricted to defining relative clauses. Authors sometimes use who and that/ which interchangeably when it should not be the case. Examples follow: "the endometrial cancer, that is the most frequent uterine cancer, was present in more than $95 \%$ of the cases"; "after seven days of TS or PTX treatment and 14 days of administering $\mathrm{CCl} 4$, the comparative analysis of the liver HP study in the rats that received only $\mathrm{CCl} 4$ and in those who received CCl4 together with TS or PTX"; "figure 7 contains a right parietal region of low density with mass effect, without calcification or hemorrhage, also representing an image who finally was diag- nosed as a diffuse astrocytoma" (5). Obviously, which should replace that in the first example, and that should have been used instead of who in the third and fourth ones. Two other examples that belong to this category of mistakes are: "we report a rare case of a 58-year-old male, with a medical history of liver cirrhosis, undergoing treatment with beta-blocker that presented with atypical chest pain, dyspnea and fatigue"; "the patients that survive need a long-term special care". In both of these examples who should have been used for the reasons described above. Advice: do not use that for human subjects in relative clauses, do not use that in non-defining relative clauses.

\section{Plural nouns with singular verbs}

Much medical terminology is rooted in Latin and Greek words with over 500 roots, prefixes, and suffixes forming the basis of fundamental medical terminology (3). Knowledge of word roots and affixes is important to any translator working with medical texts. Nevertheless, due to the fact that many European medical languages are based on this heritage, medical professionals are expected to master such vocabulary. On the other hand, languages have evolved differently and while English, for example, may have preserved plural endings rooted in Latin and Greek, other languages subjected these borrowing to their norms. Sometimes, writers/ authors may be unaware of the fact that some of the words are plural despite seeming singular. Some such examples found in the corpus are: "in literature is presented that metastases shows a higher signal intensity than normal BM on T2-weighted images" (5); "they noted that bone metastases shows well-defined edges" (5). There is a myriad of such terms with -is/ -es forms: testis, thesis, basis, sepsis, naris, etc., of which authors should be wary. 
Two other examples related to irregular plurals are: "as noted, we did reporting in tumor volumes, as data from the literature that we found shows that there is a statistically significant correlation between tumor volume and assessment of cognitive domains"; "there is no data in the literature about the life expectancy". This incorrect use of the singular verb may reside in the fact that the third person singular and plural of the present forms of the verbs are identical (arată, există) in Romanian.

Advice: whenever uncertain, check nouns for their plural forms in order to avoid such problems.

In line with singular/ plural problems, I would also like to highlight the cases when reference is made to the work of authors and their teams which should be treated as plurals. Et al. is the abbreviation for et alia (neuter plural), et alii (masculine plural), or et aliae (feminine plural), hence it should be accompanied by a plural verb since reference is made to all of the authors of that particular work. Some of the examples that I encountered in the corpus of articles are listed below: "Maccauro et al. suggests that the original location of metastases in the vertebra is in the posterior part of the body (5)"; "Algra et al. specifies that pedicles had lesions in 53 vertebrae and was never seen without the involvement of the posterior part of the vertebra" (5); "An et al. states that the aggressiveness of vertebral metastases may be reflected by the number of lesions found in a patient" (5). This again may be due to the identical form of the singular and plural verbs in Romanian, namely: sugerează, specifică, declară.

Advice: use plural verb after researcher teams with et al.

\section{Problems related to the use of prepositions}

Prepositions combine with different parts of speech. Regardless of their head, prepositional phrases are rather fixed, they rarely allow for several options, however, when they do, meanings might differ. Consequently, they have to be used in their fixed form which sometimes may pose difficulties to non-professional users of English due to, as I like to call it, crosslinguistic pollution. So are prepositional phrases in which the head is a preposition that combines with, most typically, a noun. Some such examples that my research revealed are: "classified in" - instead of into; "it did not draw attention on the diagnosis" - instead of to; "in the same time" - instead of at; "more than $80 \%$ of bone determinations are found at the axial skeleton" (5) - instead of on or in; "the vertebral pedicle is composed mainly from cortical bone" - instead of of; "in our study group only $17.47 \%$ indicate lesions in pedicles, from which $85.18 \%$ were metastases" (5) - instead of of; "the total phenolic content and antioxidant activity were determined in addition with HPLC analysis" - instead of to; "the histopathology grading was performed according with the most recent World Health Organization Classification"; "according with the published data, JS can be associated with attention deficit-hyperactivity disorder"; "according with Afifi et al., almost all patients with JS have a bleeding disorder called Paris-Trousseau syndrome" - all of these occurrences of with instead of to; "Lipton et al. suggested an angiographic classification in the right type or left-type depending from the origin of the SCA" - instead of on; "she was admitted in our Hospital" - instead of to; " $a t$ discharge (after six days), she presented complete recovery" - instead of on; "all the patients presented in the Department of ENT" instead of $t o$. 
Advice: whenever uncertain, check which preposition to use depending on context and meaning.

\section{Empty subjects}

English has two so-called empty subjects, namely it and there. There sets existence, while it is used for identifying, to refer back to something previously mentioned, something whose existence has been set (6). Many speakers of English as a foreign language encounter difficulties when using these two empty subjects and oftentimes use them mistakenly. It is the case of some of the articles included in the corpus that lies at the basis of this study. Incidentally, these problems seem to occur rather frequently in combination with passive voice. Examples follow: "in the group treated with $\mathrm{CCl} 4$ and PTX, there was observed that there are affected the hepatocytes around the central lobular vein"; "there was shown that the macrophages (Kupffer cells) play an extremely important part"; "thus, there is necessary to be determined the prothrombin index". In all of these cases, the use of it is absolutely compulsory.

As previously mentioned, the problem of empty subjects it and there often occurs in combination with passive voice. Some such examples with rewriting suggestions in parentheses are: "in the group receiving only $\mathrm{CCl} 4$ for seven days, there was highlighted a discrete hepatocytolysis and a granulovacuolar degenerescence" (a discrete hepatocytolysis and a granulovacuolar degenerescence were highlighted); "in the Kiernan space, there was observed a moderate increase of collagen fibers" (a moderate increase of collagen fibers was observed); "there were performed various IHC markers of the type CA125 and CEA, Ki67 and p53" (various IHC markers were performed); "there was identified an intensely positive epithelial immunoreactivity" (an intensely positive epithelial immunoreactivity was identi- fied); "there was established the cause of these hemorrhagic petechiae based on the aneurysmal structures observed at first examination" (the cause of these hemorrhagic petechiae was established). The problem may be rooted in the Romanian construction of these sentences, which, if translated word for word, would convey the above listed examples. Thus, the Romanian source text of these verb phrases would be: s-a evidenţiat o hepatocitoliză discretă; s-a observat o creştere moderată; s-au efectuat; s-a stabilit cauza, all of which in Romanian are impersonal constructions.

The same type of impersonal constructions lies at the basis of the following examples. The presumed Romanian source text and the improvement suggestions are given in brackets: "in the study were included patients who had developed at least one bone lesion" (5) (în studiu au fost incluşi, the study included); "it were observed also sclerotic lesions" (5) (s-au observat de asemenea, sclerotic lesions were observed); "there were diagnosed about 76960 new cases and there were recorded about 16390 deaths caused by this disease" (au fost diagnosticate circa 76960 de cazuri noi şi s-au înregistrat circa 16390 decese, about 76960 new cases were diagnosed and about 16390 deaths by this disease were recorded); "besides smoking, there were also identified other risk factors" (în afara fumatului, s-au identificat şi alţi factori de risc, other risk factors were also identified); "there were analyzed 50 cases of endometrial carcinomas" (s-au analizat 50 de cazuri de carcinom endometrial, 50 cases of endometrial carcinomas were analzyed); "it is noticed an increased level of estrogen compared to the progesterone value" (se observă un nivel crescut de estrogen, an increased level of estrogen is noticed); "numerous studies have been carried out in which it has been analyzed the corroboration of abortion with different types of cancers" (s-au efectuat numeroase studii în care s-a analizat legătura 
avortului cu diferite tipuri de cancer, numerous studies have been carried out in which the corroboration of abortion with different types of cancers has been analyzed); "it were observed also sclerotic lesions in $9.3 \%$ of cases" ( $\mathrm{s}-\mathrm{au}$ observat de asemenea leziuni sclerotice în 9,3\% din cazuri, sclerotic lesions were observed in 9.3\% of cases); "in patients with bone metastases were identified also multiple lesions" (în pacienţii cu metastaze osoase s-au identificat şi leziuni multiple, multiple lesions were also identified in patients with bone metastases); "in another study is mentioned that lesions with sizes of $5 \mathrm{~cm}$ or more are diagnosed using MRI in 100\% cases" (5) (într-un alt studiu se menţioneză că leziunile de mărime de $5 \mathrm{~cm}$ sau mai mari, another study mentions that lesions with sizes of $5 \mathrm{~cm}$ ); "there was also observed a proliferation of fibroblast and myofibroblast cells" (s-a observat şi o proliferare, a proliferation of fibroblast and myofibroblast cells was also observed); "there was recommended the performance of a cervix biopsy and there was established the diagnosis of a possibly serous endocervical adenocarcinoma" (s-a recomandat efectuarea unei biopsii cervicale şi s-a stabilit diagnosticul, the performance of a cervix biopsy was recommended and the diagnosis of a possibly serous endocervical adenocarcinoma was established); "it is a rare syndrome, there have been reported over 200 cases" (este un sindrom rar, s-au raportat peste 200 de cazuri, over 200 cases have been reported). And the list may go on, however, the other instances are highly similar to the ones mentioned above.

Advice: differences between languages exist, thus, adhering to the norms of the target language is of paramount importance.

\section{Extra words}

Another problem seems to be that of the presence of an extra word. Most frequently, the extra one is the English definite article in instances where
Romanian would use it, as highlighted in the following examples: "they were examined under the Nikon 55i microscope" (here, Romanian would not use a definite article); "the abortion should be considered as a final measure that can be taken" (avortul ar trebui considerat); "starting from this point of view, the women have to pay attention to the prophylaxis" (femeile trebuie să fie atente); "we consider that as soon as the women will understand the negative consequences of this dangerous practice" (considerăm că de îndată ce femeile vor înţelege); "the women must be very well informed about this dangerous practice" (femeile trebuie să fie bine informate); "to prevent and even stop the abortions" (pentru a preveni şi chiar opri avorturile); "in the present study, bone metastases were lytic, sclerotic or mixed, as were presented in the Table 5" (5) (aşa cum au fost prezentate în Tabelul 5); "the adults over the age of 50 are prone to meningiomas" (adulții de peste 50 de ani); "the brain tumors are the second type of cancer in terms of frequency" (tumorile cerebrale); "the mortality is higher in more developed countries" (mortalitatea este mai ridicată); "the survival rates differ significantly by histology and age" (ratele de supravieţuire); "there are suggestive clinical signs and symptoms but for diagnosis, the cytogenetic testing is mandatory" (testarea citogenetică este obligatorie).

Medical journal guidelines recommend keeping an article as simple and clear as possible, because scientific texts are expected to be concise since "concision reduces the possibility of distortions in the information" (7). As such, journal requirements view word number limits as well. With this in mind, translators must know to what extent the space factor has to be taken into consideration in their choice of wording (8) because there may be differences in the number of words used in the target language and that used in the source language. 
A useful method of reducing word count in such articles is removing any redundancies without altering the meaning in any way. For instance, the word total is often unnecessary as in the following examples: "initial WLC identified a total number of 99 bladder tumors"; "the group of patients with hematological malignancies comprised a total of 73 cases with multiple myeloma" (5). In the analyzed corpus of medical articles, I also encountered another instance of an extra word, namely: "in both of these two cases, their final diagnosis was diffuse astrocytoma". Here again, Romanian would use the numeral: în ambele dintre aceste două cazuri, although its use could be termed incorrect since ambele, just as the English both, refers to two.

Advice: adhering to the norms of the target language regarding the use of the definite article is essential as is removing any unnecessary words, despite their presence in the source text.

\section{Wrong choice of words}

Problems in the case of translation of medical articles arise both from differences between the two language systems and from conceptual differences (9). This is due to the fact that languages work differently and not all of them have terms to refer to different notions and concepts, or there may be cases when a particular word refers to different concepts in pairs of languages, Romanian and English in our case. Thus, the next set of problems that I would like to emphasize is that of wrong choices of words. Some of these seem to be word for word translations as many of them are words that do not adhere to English language norms. Examples are numerous: "the hepatocytes had normal form and size" (i.e. shape, formă in Romanian); "while the type 1 lesions are hormonally sensible and represent more than $80 \%$ of the endometrial cancer" (i.e. sensitive, sensibil in Romanian); "coloration with Hematoxylin-Eosin (HE) staining was performed" (i.e. staining, coloraţie in Romanian); "the $a v$ erage age was 43" (i.e. mean, medie in Romanian); "regarding paraclinical tests, which can indicate the presence of an oncological uterine pathology" (i.e. disease, patologie in Romanian is also used with the meaning of disease); "with a young age at the apparition of the disease" (i.e. onset, apariţie in Romanian); "in the specialty literature" (i.e. medical, Romanian uses literatura de specialitate); "in most studies, the type of abortion is not specified, spontaneously or provoked" (i.e. spontaneous, spontan in Romanian, the masculine singular adjective which modifies type is identical to the adverbial form); "a scar in the conjunctive tissue appears at the respective level" (i.e. connective, conjunctiv in Romanian); "in this case, it must be established whether bone lesions belong to primary neoplasia, or are due to newly cancer" (5) (i.e. new, nou in Romanian, the masculine singular adjective which modifies cancer is identical to the adverbial form); "this requires theirs differential diagnosis" (i.e. their, lor in Romanian, identical forms for both the third person plural possessive pronoun and possessive adjective); "appearing slightly bright than muscle tissue" (i.e. brighter); "if multiple bone lesions were presents" (i.e. present, prezent in Romanian has the plural feminine form of prezente, hence the plural that modifies lesions); "for bone marrow biopsy is necessary a fragment of at least $1 \mathrm{~cm}$ length for a properly histopathological examination" (5) (i.e. proper, adecvat in Romanian, which has the same form for both the singular masculine adjective and the adverb); "after decalcification and automatic processing, the samples were paraffin embedding" (5) (i.e. embedded); "in March 2017, the patient presented for a new treatment stage of neurological rehabilitation, still she accused intense headache that did not respond to any conservative therapy" (i.e. complained of, the verb a acuza is used in Romanian); "from the physiological antecedents of these young patients are very important 
the high number of induced abortions at young age" (i.e. history, antecedente in Romanian); "treatment does not reduce mortality in the majority of cases, the prognostic being poor" (i.e. prognosis, prognostic in Romanian); "the diagnostic is based on clinical symptoms like nasal obstruction, epistaxis, purulent rhinorrhea, sore throat" (i.e. diagnosis, diagnostic in Romanian). Advice: it is always useful to check dictionaries or other medical texts whenever uncertain about a particular choice

\section{Wrong choice of tense}

Another set of problems that I encountered in the articles of the corpus is that of the wrong choice of tense. Examples follow: "in the last years, the incidence of the endometrial carcinoma is growing continuously" (i.e. has been growing, Romanian lacks continuous and perfect tenses, hence it would use the present); "patients who presented abortions in the case history, and the rest of the cases have constituted the control group" (i.e. constituted); "the patients have in their history at least one abortion, the majority (79.1\%) have induced abortions in the first three months of pregnancy (i.e. had, had); "genes in this region are playing a critical role in the normal development of brain, heart and craniofacial development" (i.e. play); "we consider that as soon as the women will understand the negative consequences of this dangerous practice" (i.e. understand/ have understood). This latter inconsistency may lie in the fact that Romanian freely and interchangeably uses either the present or the future tense both in the subclause and the main one.

Advice: grammar rules regarding the use of tenses in the target language should always be applied regardless of the choice in the source language.

\section{Wrong word order}

I would also like to point out the fact that the study of the corpus revealed instances of wrong word order. However, some of the following examples are accompanied by other problems as well which are not going to be discussed here: "in some cases of organic cancer can occur a hematological malignancy" (5) (i.e. a hematological malignancy can occur, this may be due to the fact that Romanian would use this particular word order poate să apară o malignitate hematologică); "for bone marrow biopsy is necessary a fragment of at least $1 \mathrm{~cm}$ length for a properly histopathological examination" (5) (i.e. a fragment of at least $1 \mathrm{~cm}$ length is necessary, Romanian would use the following construction: este necesar un fragment de cel puţin $1 \mathrm{~cm}$ lungime); "of the 309 patients, $44.33 \%$ were diagnosed with a form of hematological neoplasia, and the $55.66 \%$ remaining had another form of cancer" (5) (i.e. the remaining 55,66\%, again, Romanian would be much more flexible in terms of word order: cele 55,66\% rămase); lesions in $\mathrm{MM}$ are located rarely in pedicles (i.e. are rarely located, sunt localizate rareori); "the difference between the two genders being not statistically significant" (i.e. not being).

Advice: grammar rules on word order should always be kept to despite the flexibility of word order in the source language.

\section{Incomplete sentences and missing words}

While not very frequent in number of occurrences, I would like to include the problem of incomplete sentences and missing words. The study of the corpus of articles revealed the following instances of such cases: "IHC staining was carried out on $2 \mu \mathrm{m}$ thickness paraffin-wax sections using UltraVision Large Volume Detection System (Thermo Fisher Scientific, USA), 
in accordance with the manufacturer 's" (5) (i.e. manufacturer's recommendation); "the fourth ventricle without deviation on the medial line" (a verb is utterly missing); "isolated LS thrombosis has frequently described in the past in ear or mastoid infections" (i.e. has been frequently described).

Advice: double checking the target text can be a useful method to avoid such inconsistencies and mistakes.

\section{Conclusion}

In our contemporary society, the use of English is inevitable for whoever works in medical or pharmaceutical fields because most scientific articles are published in English in various journals across the Globe. Supposedly, many of the authors of such articles are not proficient users of English, hence, many mistakes can be found in biomedical articles.

The question of who is more suited to translate a medical text, whether a linguist or a medical professional finds its answer in Jo Ann Cahn's idea according to which "a professional translator (...) with medical knowledge is probably better than a dilettante doctor with some linguistics knowledge" (10).

Solid knowledge of the target language, in our case English, is essential for anyone who produces medical texts, whether authors/ scientists, or translators. On the other hand, some knowledge of medical science is also useful for any translator who works with these types of texts. Nevertheless, knowledge of language or knowledge of medicine alone is insufficient, but following language norms and rules, checking for any unknown terminology or vocabulary, following the three-step model proposed by Montalt \& González Davies (3), that is, composing, crafting, and improving, double checking the final product can render correctly written texts from a linguistic and terminological point of view. Whether it is the case of translations or that of self-translations, we have to bear in mind that "languages may converge but not merge: it is in the act of translation that their apartness manifests itself. [...] And yet we hold the act of translation the most successful which contains no evidence at all of the apartness of languages" (11).

\section{References}

1. McMorrow L. "Breaking the Greco-Roman Mold in Medical Writing: The Many Languages of 20th Century Medicine" in Fischbach, Henry (ed.) Translation and Medicine, Amsterdam/Philadelphia: John Benjamins Publishing Company. 1998; Volume X:13-27. DOI: 10.1075/ata.x.04mcm

2. Olohan M. "Scientific and technical translation" in Routledge Encyclopedia of Translation Studies, 2nd edition, Abingdon/ New York: Routledge. 2009;246-9.

3. Montalt V, González Davis M. Medical Translation Step by Step. Learning by Drafting, Manchester/ Kinderhook: St. Jerome Publishing. 2007.

4. Scanlan CL. Types of Articles, available online at http:// www.umdnj.edu/idsweb/shared/types_of_articles.htm , viewed July 14, 2012.

5. Bratu AM, Raica VP, Salcianu IA, Zaharia C, Popa VB, Lupu AR, et al. MRI differential diagnosis: bone metastases versus bone lesions due to malignant hemopathies. Rom J Morphol Embryol. 2017;58(4):1217-28.

6. Alexander LG. Longman English Grammar, London and New York: Longman. 1994.

7. Cabré TM. Terminology: Theory, Methods, and Applications, Amsterdam: John Benjamins Publishing Co. 1999. DOI: $10.1075 /$ tlrp. 1

8. Fischbach H. "Problems of Medical Translation" in Bulletin of the Medical Library Association. 1962; 50(3):462-72.

9. Pilegaard M. "Translation of Medical Research Articles" in Anna Trosborg (ed.), Text Typology and Translation, Amsterdam/ Philadelphia: John Benjamins Publishing Company. 1997;159-84. DOI: 10.1075/ btl.26.13pil

10. O’Neill M. "Who Makes a Better Medical Translator: The Medically Knowledgeable Linguist or the Linguistically Knowledgeable Medical Professional? A Physician's Perspective" in Fischbach, Henry (ed.) Translation and Medicine, Amsterdam/ Philadelphia: John 
Benjamins Publishing Company. 1998; Volume X:6980. DOI: 10.1075/ata.x.09one

11. Sturrock J. "Writing between the Lines: the Language of Translation" in Baker, M. (ed.) Critical Readings in Translation Studies, London/ New York: Routledge. 2010:49-64. 